\title{
Fingerprinting sources of salinity in a coastal chalk aquifer in Denmark using trace elements
}

\author{
Christian Knudsen* ${ }^{\circ}$, Klaus Hinsby ${ }^{\oplus}$, Rasmus Jakobsen ${ }^{\oplus}$, Lars Juul Kjærgård, Per Rasmussen \\ Geological Survey of Denmark and Greenland, Copenhagen, Denmark
}

\begin{abstract}
Salinity levels above the drinking water standard $\left(>250 \mathrm{mg} / \mathrm{l} \mathrm{Cl}^{-}\right)$are observed at shallow depth in a Maastrichtian chalk aquifer on the island of Falster, south-eastern Denmark. To understand the source of the salt, 63 samples from 12 individual, $1 \mathrm{~m}$, screened intervals between 14 and $26 \mathrm{~m}$ b.s. were collected from 1 May to 4 June 2018. The samples were collected during a tracer test to estimate the dual porosity properties of the chalk and were analysed for a wide range of elements. Furthermore, samples from the Baltic Sea and from deeper saline aquifers in the area (40 and $85 \mathrm{~m}$ b.s.) were analysed for comparison. The geochemical data were analysed using an unsupervised machine-learning algorithm, selforganising maps, to fingerprint water sources. The water composition in the screened intervals at various stratigraphic levels has specific geochemical fingerprints that are maintained for the first days of pumping and are distinct amongst the different levels. This suggests an evolution in water composition because of reaction with the chalk. Water composition is distinct from both seawater from the nearby Baltic Sea and salty water from deeper levels of the reservoir. Thus, neither up-coning of salty water nor intrusion of seawater caused the elevated salinity levels in the area. The slightly saline composition of groundwater in the shallow aquifer (14-26 $\mathrm{m}$ b.s.) is more likely because of incomplete refreshing of the salty connate water in the chalk during the Pleistocene and Holocene. Furthermore, the geochemical fingerprint of salty water from the deeper aquifer at $40 \mathrm{~m}$ was similar to water from the Baltic Sea, suggesting a Baltic Sea source for salt in the aquifer at $40 \mathrm{~m}$ b.s., c. $100 \mathrm{~m}$ from the coast. Statistical analysis based on self-organising maps is an effective tool for interpreting a large number of variables to understand the compositional variation in an aquifer and a useful alternative to linear dimensionality-reduction methods such as principal component analysis. The approach using the multi-element analysis combined with the analysis of self-organising maps may be useful in future studies of groundwater quality.
\end{abstract}

\section{Introduction}

Sustainable water resources management and saltwater intrusion in coastal aquifers are huge challenges globally, and these challenges are projected to be more severe in the future due to climate change and sea-level rise (Hinsby et al. 2016; Rasmussen et al. 2013).

\author{
*Correspondence: ckn@geus.dk \\ Received: 20 Aug 2020 \\ Accepted: 12 Mar 2021 \\ Published: 23 July 2021
}

Keywords: fingerprinting, groundwater, chalk aquifer, trace elements, selforganising map

\author{
Abbreviations: \\ b.s.: below surface \\ BMU: best matching units \\ DGU: Danish Geological Survey \\ GEUS: Geological Survey of Denmark and \\ Greenland \\ ICP-MS: inductively coupled plasma mass \\ spectrometry \\ SOM: self-organising map
}

GEUS Bulletin is an open access, peerreviewed journal published by the Geological Survey of Denmark and Greenland (GEUS). This article is distributed under a CC-BY 4.0 licence, permitting free redistribution, and reproduction for any purpose, even commercial, provided proper citation of the original work. Author(s) retain copyright.

Edited by: Julian Koch (GEUS, Denmark)

Reviewed by: Søren Munch Kristiansen (Aarhus University, DK), Sascha Müller (University of Copenhagen, DK), Boris van Breukelen (TU Delft, NL)

Funding: See page 11

Competing interests: None declared

Additional files: See page 11 
Saltwater intrusion may be the most important challenge in coastal aquifers, and there is a strong need for the development and implementation of effective mitigation and remediation measures (Hinsby et al. 2018). Designing efficient mitigation and remediation measures requires an understanding of the sources and occurrence of the saltwater. Possible sources include saltwater from nearby seas, marine deposits in or adjacent to the aquifers or saline groundwater recharge due to decreasing and/or increasing precipitation and evaporation. All these sources may affect the salinity of the aquifers in some areas, while in others perhaps only one of the sources is of significance.

The final decision on which method should be implemented to protect coastal water resources ultimately relies on a sound understanding of the location and nature of the salinisation sources. Here, we propose a new approach based on self-organising maps (SOMs) for fingerprinting the sources of increasing salinity in aquifers using an example from a coastal confined chalk aquifer on southern Falster, Denmark (Fig. 1A).

Elevated salinity levels were observed at shallow depth in a Maastrichtian chalk aquifer on the island of Falster, south-eastern Denmark (Fig. 1) as early as 1936 (Ødum \& Christensen 1936). Chloride concentrations of c. 200-300 mg/l Cl- are locally found down to c. $25 \mathrm{~m}$ below the surface ( $\mathrm{m}$ b.s.). The chloride content is generally below the WHO/EU drinking-water standard of 250 $\mathrm{mg} / \mathrm{l} \mathrm{Cl}-$ but high compared with the recent groundwater recharge and frequently above a threshold value of $c$. $200 \mathrm{mg} / \mathrm{l} \mathrm{Cl}$ proposed for Danish groundwater bodies based on the European Water Framework and Groundwater Directives and related guidelines (Hinsby et al. 2008). Below this, between 25 and $45 \mathrm{~m}$ b.s., the salinity is c. $500 \mathrm{mg} / \mathrm{C} \mathrm{Cl}^{-}$and it increases with depth to c. 4000 $\mathrm{mg} / \mathrm{l} \mathrm{Cl}{ }^{-}$at $80 \mathrm{~m}$ depth and further to c. $20000 \mathrm{mg} / \mathrm{l} \mathrm{Cl}$ at about 150 m b.s. (Rasmussen et al. 2013). A recent status assessment of Danish groundwater bodies has identified the chalk aquifer on Falster as having poor chemical and quantitative status due to indications of freshwater mining and saltwater intrusion in several areas (Henriksen et al. 2019). This agrees with a previous assessment, which concluded that new innovative subsurface water solutions involving managed aquifer recharge (Zuurbier et al. 2017) will most probably be required to secure future sustainable water supply at least in the southern part of Falster (Hinsby et al. 2018).

The objective of this study was to investigate the origin of the elevated salinity in the area: is it caused by intruding saltwater from the Baltic Sea, up-coning of salt connate water (water trapped in the pores of the chalk when deposited) from below due to pumping, incomplete leaching of connate water in the upper part of the chalk aquifer or by infiltration of recharge through Holocene marine sediments above the chalk aquifer (Hinsby et al. 2012; Rasmussen et al. 2013)? Understanding the sources of the saltwater have implications for the choice of measures implemented to control further increases of chloride in water supply wells in the area (e.g. Zuurbier et al. 2017).

To understand the sources of chloride (saltwater) in water-supply wells, we analysed (1) water from the
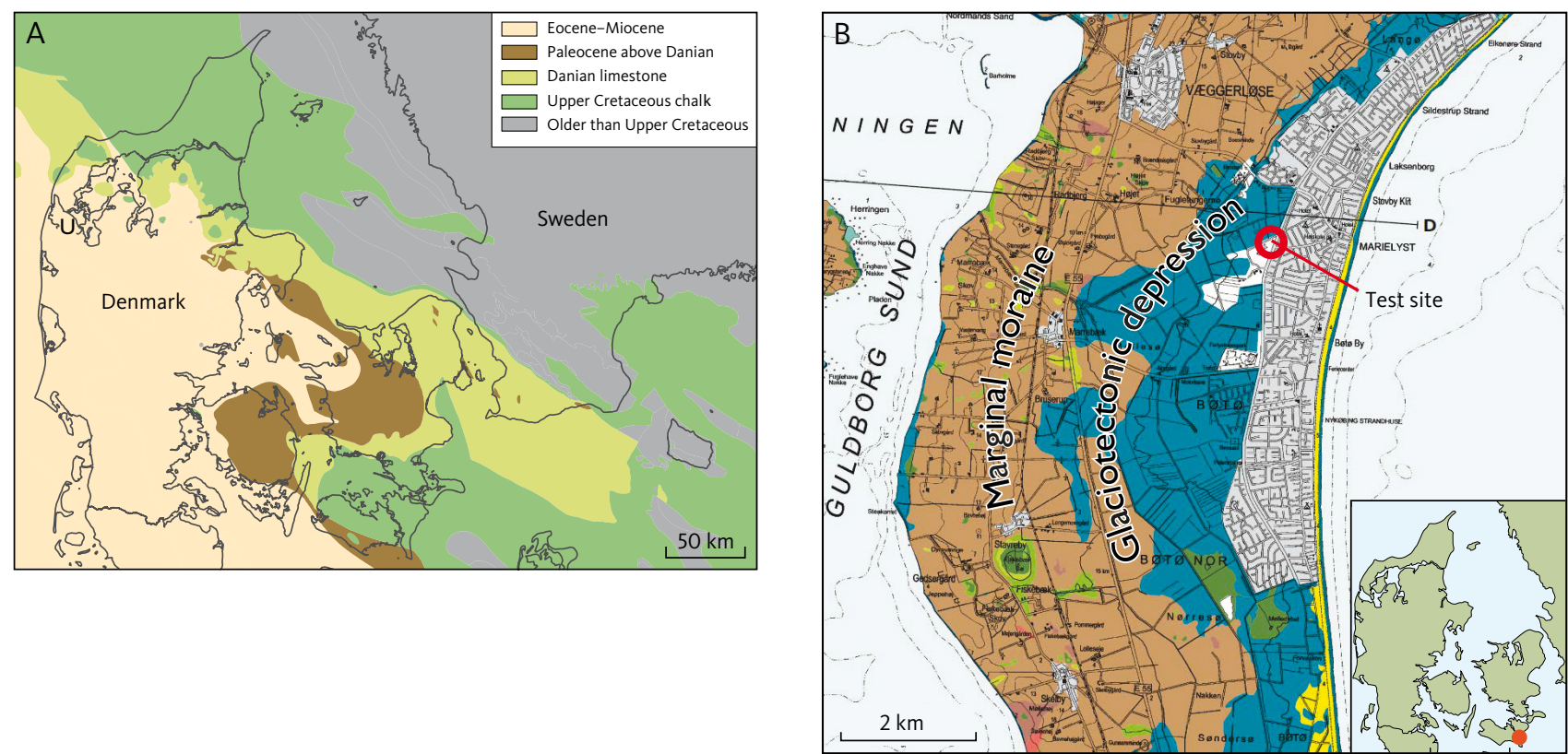

Fig. 1 Location and geological setting of the study site. A: Geology of Denmark. B: Focussed view of the test site on the island of Falster, south-eastern Denmark. The location of the test site (Fig. 3) is indicated by a red circle. Modified from Pedersen et al. (2018). 
Baltic Sea, (2) connate water from deeper levels in the chalk, (3) water from filters in wells in the chalk at depths from where the water company abstracts drinking water and (4) the variation of the composition over time while pumping on the wells.

The main aquifer in the area consists of Maastrichtian chalk in which the Quaternary glaciations have caused intense fracturing in the upper 10-43 $\mathrm{m}$ of the chalk. The glacial disturbances include dislocation and development of a chalk-glaciotectonite locally containing Quaternary sediments (Pedersen et al. 2018). Below 45 $\mathrm{m}$ b.s., the gamma-ray signal increases suggesting that the chalk is marly and the transmissivity in the chalk is lower here.

In Danish chalk aquifers, the residual saltwater is usually completely flushed out in the upper 50-80 m (Bonnesen et al. 2009). Below this follows a transitional zone with increasing salinity to depths of 150-200 m where the chloride concentration exceeds $19000 \mathrm{mg} / \mathrm{l}$, similar to deeper parts of the chalk in, for example, England (Edmunds et al. 1987). This level of salinity is similar to oceanic seawater and may represent connate water.

The low-lying glacial depression south-east of the marginal moraine (Fig. 1B) formed a shallow lagoon in the Holocene until land reclamation was initiated in the early 1860s, and it became operational from around 1900. The area is now covered by a thin layer of Holocene marine sand (Figs 2, 3B).

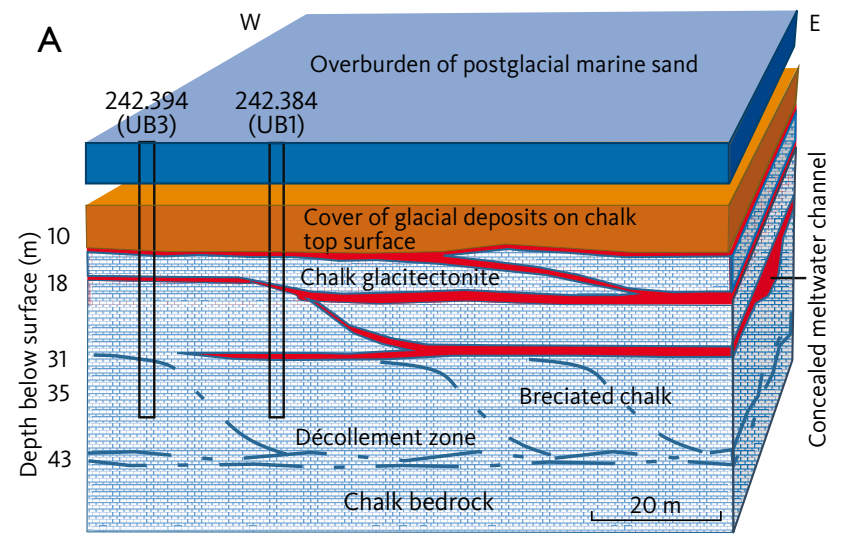

\section{Methods}

\subsection{Sampling strategy}

Groundwater is pumped from well UB2 and re-injected in well UB1 creating a dipole flow system between the two wells (Fig. 4). The tracer ( $\mathrm{NaCl}$ ) is injected in well T2, and the breakthrough is observed in samples collected from the 14 screens in wells CMT 1 and 2. The location of these wells is marked on Fig. 4. Trace elements (measured by ICP-MS, details given) and chloride (measured by ion chromatography) were analysed in samples collected from CMT 1 and 2 wells. Electrical conductivity was continuously monitored in the same wells by WTW instruments using the calibrated WTW electrodes. The aim of the tracer test was to assess the dual porosity characteristics of the chalk.

\subsection{Sample collection and analysis}

Two closely spaced multi-level monitoring wells (CMT 1 and 2), about $20 \mathrm{~m}$ downstream of a water supply well (242.212), were sampled in the Maastrichtian chalk aquifer (Fig. 4). A total of 58 ground water samples were taken from 12 1-m screens, between 14 and $26 \mathrm{~m}$ b.s. The samples were collected during continuous pumping on the wells between 1 May and 4 June 2018.

In the period from 1 May to 22 May 2018, $4.9 \mathrm{~m}^{3} / \mathrm{h}$ were pumped from a well (UB2) $3 \mathrm{~m}$ downstream (in the direction of the regional flow during the tracer test) from

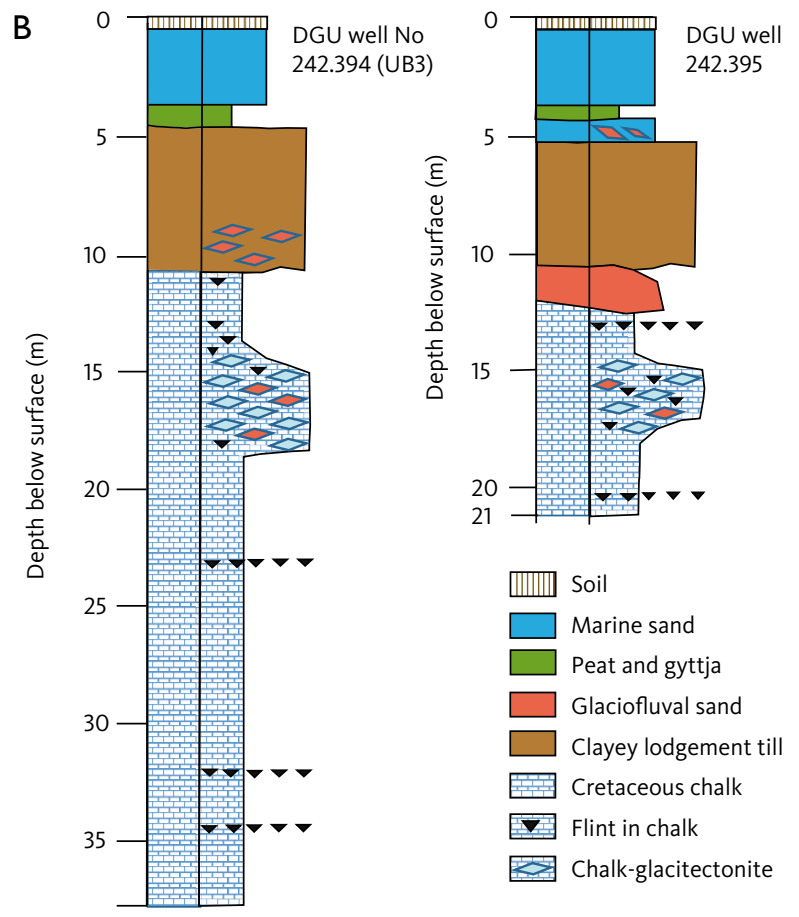

Fig. 2 A: Block diagram of the test site. Note that a significant part of the tracer tests described in this study takes place in the glacitectonite between 15 and 20 m b.s. (modified after Pedersen et al. 2018). Two wells are shown: DGU well no. 242.394 (UB3) and 242.384 (UB1). B: Schematic geological logs in two wells, DGU well no. 242.394 (UB3) and 242.395. 


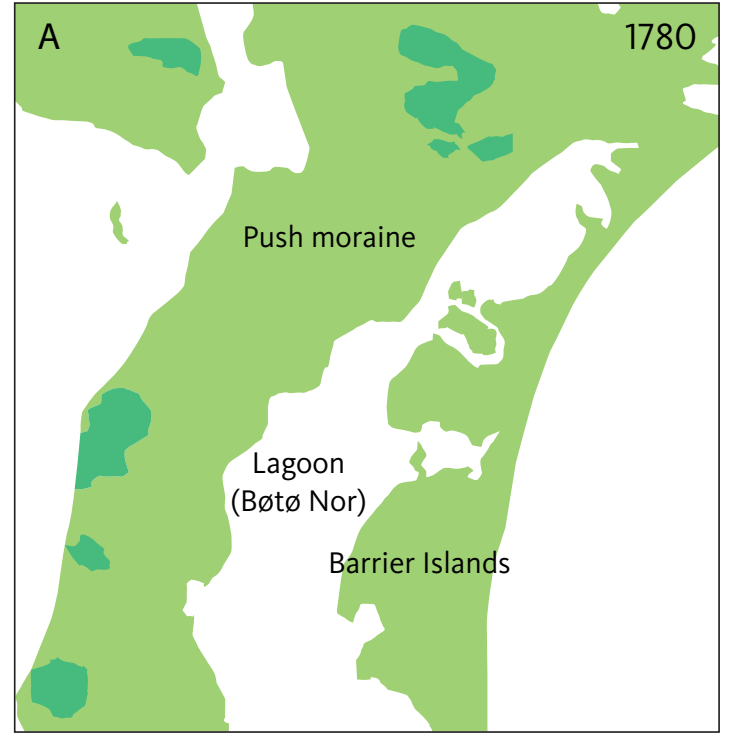

W

Elevation

m a.s.l.

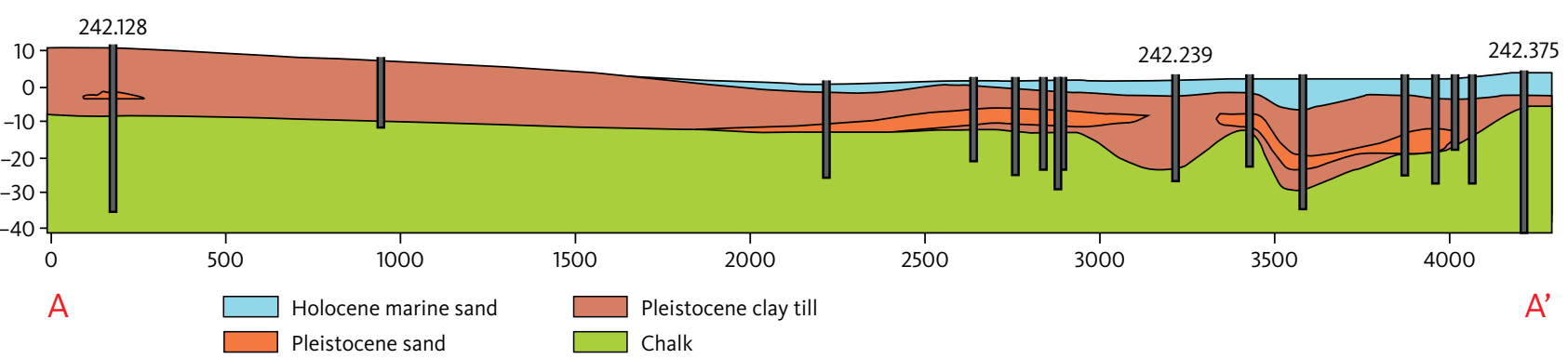

Fig. 3 A: The study area in 1780, about 80 years before land reclamation was initiated. B: The study area in 2021 with drainage canals developed in the land reclamation project initiated in 1861. The tracer test site investigated in this study (Fig. 4) is established at well no.: 242.212 (yellow triangle). The cross-section A-A' through the study area and tracer test site is shown in the lower panel. The local water works abstracts groundwater from 11 wells in the upper $10 \mathrm{~m}$ of the chalk in the area.

the monitoring wells (CMT 1 and 2), and $2.6 \mathrm{~m}^{3} / \mathrm{h}$ were re-injected into the well (UB1) c. $30 \mathrm{~m}$ upstream from the monitoring wells (Fig. 4). The constant pumping created a constant flow field during the dipole tracer test passing through the monitoring wells, such that the water sampled from a given sampling screen should represent the same volume of the aquifer for the pumping period. From 22 May to 4 June 2018, the pumping was set to $9.1 \mathrm{~m}^{3} / \mathrm{h}$, and the re-injection was set to $5.3 \mathrm{~m}^{3} / \mathrm{h}$.

A further five samples were collected from two other wells in the area about halfway through the experiment (17-18 May): three samples representing marine water from the Baltic Sea, one sample from $40 \mathrm{~m}$ b.s. (well site DGU 242.375, $100 \mathrm{~m}$ from the Baltic Sea; Fig. 3) and one sample representing deeper groundwater from $85 \mathrm{~m}$ b.s. (well site DGU 242.344, $2.8 \mathrm{~km}$ from the Baltic Sea; Fig. 3B). The purpose of this sampling was to obtain the composition of possible end-members for comparison.

All samples for the analysis of trace elements were collected by syringes and injected directly into prepared and acidified $20 \mathrm{ml}$ polyethylene vials through 0.45 $\mu \mathrm{m}$ filters and kept at c. $8^{\circ}$ Celsius until analysis. The samples from the multi-level wells (CMT 1 and 2) were collected by syringes directly from the $4 \mathrm{~mm}$ tubing constantly discharging water from the different screens at c. $80 \mathrm{ml}$ per min.

The samples were analysed for trace elements at GEUS using inductively coupled plasma mass spectrometry (ICP-MS) and the Perkin-Elmer 'TotalQuant' method. Methods are provided in Supplementary File S1, online. We analysed for the following elements: $\mathrm{Al}, \mathrm{As}, \mathrm{B}, \mathrm{Ba}, \mathrm{Ca}$, $\mathrm{Ce}, \mathrm{Co}, \mathrm{Cr}, \mathrm{Cs}, \mathrm{Cu}, \mathrm{Fe}, \mathrm{K}, \mathrm{La}, \mathrm{Li}, \mathrm{Mg}, \mathrm{Mn}, \mathrm{Mo}, \mathrm{Na}, \mathrm{Ni}, \mathrm{P}, \mathrm{Rb}$, $\mathrm{Sc}, \mathrm{Se}, \mathrm{Si}, \mathrm{Sr}, \mathrm{Th}, \mathrm{Ti}, \mathrm{U}, \mathrm{V}, \mathrm{Y}$ and $\mathrm{Zn}$ (the data are available online in Supplementary File $\mathrm{S} 2$ ).

\subsection{Self-organising map analysis}

The unsupervised machine-learning algorithm, self-organising map (SOM), provides a non-linear method for visualising multi-dimensional data, and it is used here to analyse the geochemical data. The SOM may 


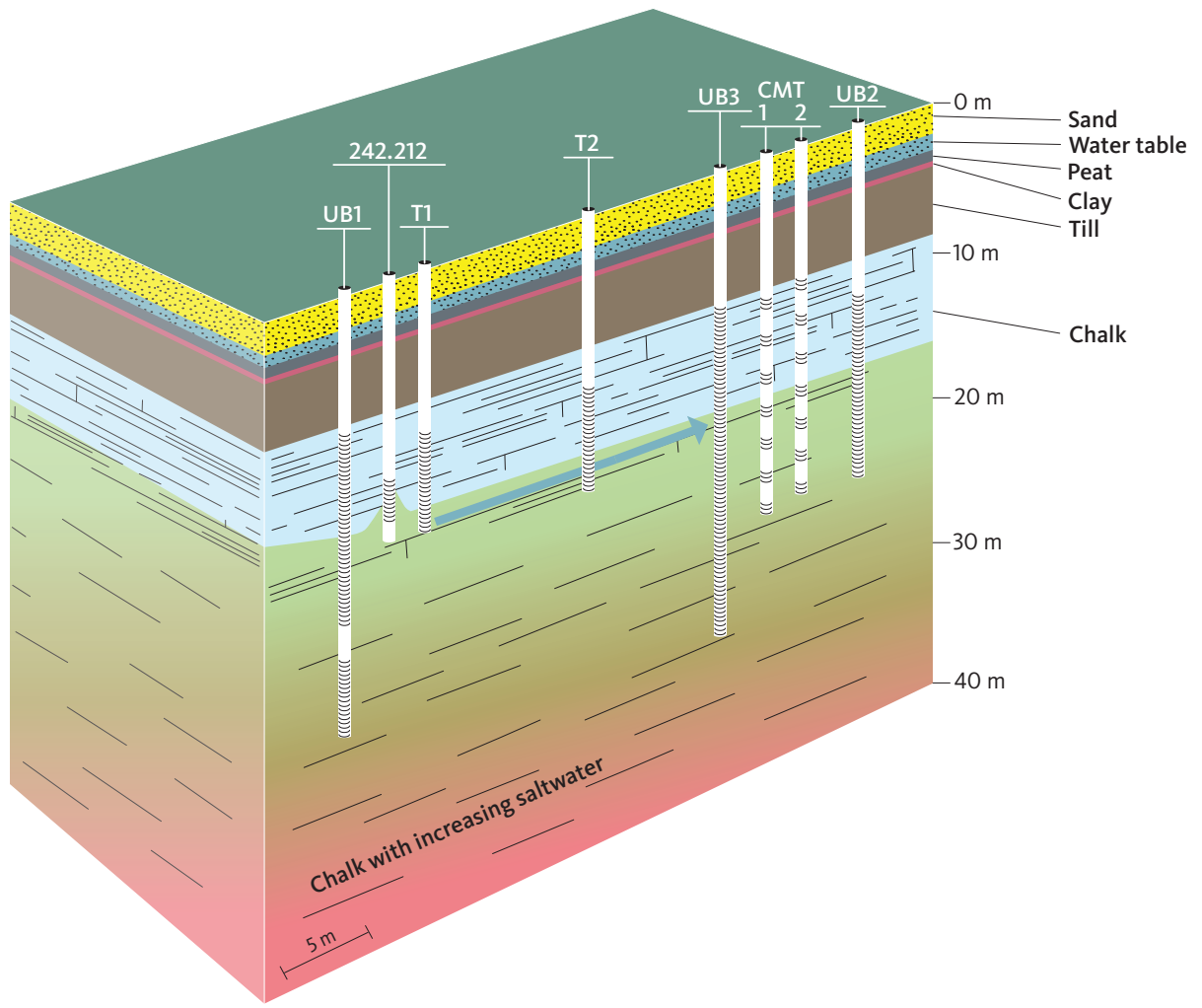

Fig. 4 Design of the tracer test site and wells (UB1, T1, T2, UB3, CMT1 and $\mathbf{2}$ and UB2). Red colours from about $30 \mathrm{~m}$ b.s. indicate high salinity with depth. The supply well is well 242.212, location on Fig 3. Green arrow indicates direction of the flow during the tracer test.

be viewed as a two-dimensional grid onto which the multi-dimensional input data are projected or mapped. Here, we aim to reduce the complexity of our large dataset (27 elements analysed in 63 samples) into a set of geochemical fingerprints for each sample. These fingerprints can be represented in two dimensional maps, such that similar objects are close together, and dissimilar objects are far away from each other. In other words, the SOM processing finds an approximation of the data by mapping the input data into another dataset, which has fewer datapoints than the initial dataset. This approximation, referred to as the best matching units (BMUs), has the same amount of data types (i.e. same dimensionality) as the input data. The BMUs are presented in the SOM as a two-dimensional map and referred to as the SOM-space. Each BMU is associated with a cell in the matrix or SOMspace, and they are ordered in the matrix such that similar BMUs are adjacent to each other in the two-dimensional map. Although the SOM is two-dimensional, the multi-dimensionality of the input data is retained by the dimensionality of the BMU. Each of the input datapoints has a BMU to which the data are most similar. Several input data may be associated with the same BMU, in which case the SOM presentation may be viewed as a classification of the input data. The SOM is discretised in a pre-selected number of rows and columns (grid or matrix representation). Thus, the original multi-dimensional data are mapped into a new data space with only two dimensions and fewer data. In our case, the number of rows and columns are 5 and 11 , respectively (Fig. 5A). The number of cells or elements defines the data reduction applied to the initial data. In this case, a reduction from 63 data samples analysed for 27 elements $=1701$ datapoints reduced to a maximum of $5 \times 11=55$ datapoints (Fig. 5). The grid size is determined based on a heuristic approach. Large maps produce a large number of small but 'compact' clusters (records assigned to each cluster are quite similar). Small maps produce fewer but more generalised clusters. A 'right number of clusters' does not exist, especially in real-world datasets. It all depends on the detail in which you examine your dataset. The grid size used in this study is calculated by SOM based on the size of the dataset.

The SOM analysis is based on the commercial software package SiroSOM ${ }^{\mathrm{TM}}$. The grid size used in this article is calculated by SiroSOM based on the size of the dataset. The BMU colours are generated by SiroSOM, and the timeline and cross-plots are generated using a Matlab script developed by the Geological Survey of Denmark and Greenland (GEUS). The procedure used here is further described in Supplementary File S1.

The positions of the datapoints (Fig. 5B) represent the analytical results, whereas the colours of the dots represent their position in the entire dataset. The colour scale is chosen by the algorithm, but the colours are chosen so that points with colours close to each other represent 
A

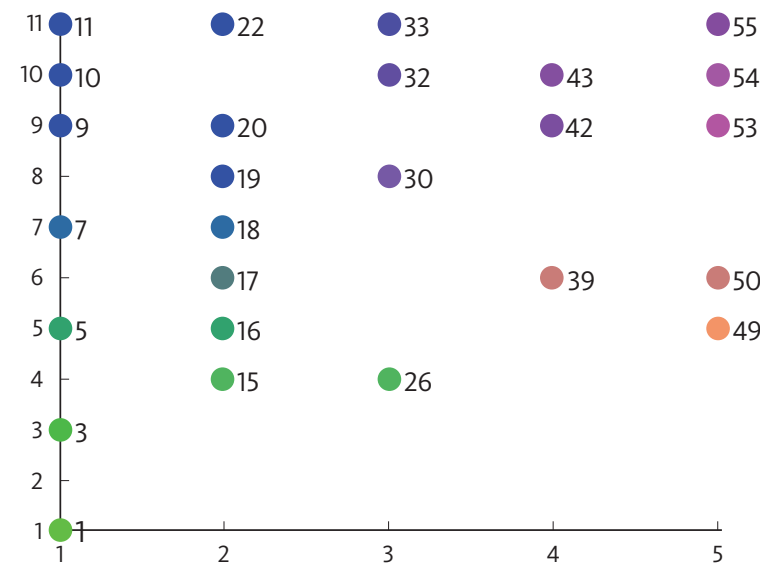

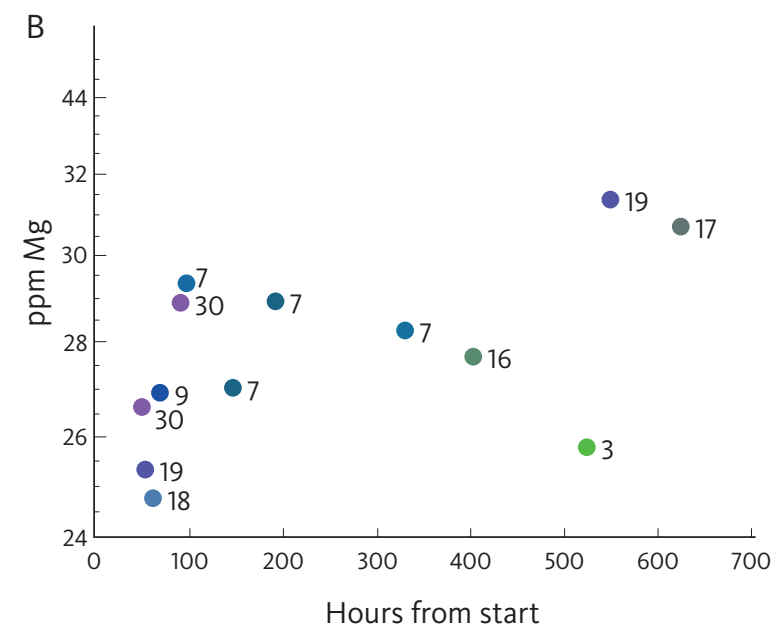

Fig. 5 Self-organising maps (SOMs): A: Each original datapoint is associated with a best matching units (BMU) point and only 26 out of $55 \mathrm{BMU}$ points are selected. No units. B: Example SOM for $\mathrm{Mg}(\mathrm{ppm})$ versus time: the original datapoints with the associated BMU colours and numbers are displayed.

samples with compositions that are close to each other in the 27-dimensional space. Detailed information on SOM can be found in Kohonen $(1982,1990,2001,2013)$ and Kalteh et al. (2008). The SOM method has recently been used in the analysis of groundwater geochemical data in a coastal aquifer near Venice (Dalla Libera et al. 2020) and in geochemical pattern recognitions of deep thermal groundwater in South Korea (Kim et al. 2020).

\section{Results}

The arrival of the tracer is seen as an increase in the conductivity in the monitoring wells (Fig. 6). The timing varies among the three different levels with maximum effect c. $100 \mathrm{~h}$ after the start of the experiment at 15.5 $\mathrm{m}$, whereas the tracer peak arrives later at the 19.5 and $23.5 \mathrm{~m}$ levels and is much more diffuse. Another injection of tracer was initiated on 23 May 2018 peaking on 25 May at $15.5 \mathrm{~m}$. The increased pumping and reinjection rate effects the time it takes for the tracer to pass the monitoring well (Fig. 6). The gap in the measurements of electrical conductivity (EC) in Fig. 6 was caused by power loss on the EC meter.

\subsection{Hydro-chemical fingerprints vary both with stratigraphy and time}

Concentrations of, for example, $\mathrm{Na}, \mathrm{Mg}, \mathrm{Mn}, \mathrm{Co}, \mathrm{Sr}$ and $\mathrm{Zn}$ vary with depth in the wells and with time during the conducted tracer test, 1 May to 4 June 2018 (Fig. 7). For the first c. $75 \mathrm{~h}$, the composition of the water is rather constant at the three levels (Fig. 7). The contents of $\mathrm{Na}$, $\mathrm{Mg}, \mathrm{Sr}, \mathrm{Zn}, \mathrm{Mn}$ and Co are high at the $19.5 \mathrm{~m}$ level relative to the 15.5 and $23.5 \mathrm{~m}$ levels and distinctly different from both the 15.5 and the 23.5 levels. The contents of $\mathrm{Mg}, \mathrm{Sr}$ and $\mathrm{Zn}$ at the $15.5 \mathrm{~m}$ level are low, and the content of $\mathrm{Mn}$ is high relative to the $23.5 \mathrm{~m}$ level; the compositions of the water at the different stratigraphic levels are all distinct from each other.

The content of Na varies among the different stratigraphic levels (Fig. 7). The content of $\mathrm{Mg}$ is relatively low in the upper $(15.5 \mathrm{~m})$ level compared with both the middle $(19.5 \mathrm{~m})$ and lower $(23.5 \mathrm{~m})$ level, and the concentration stays more or less constant over the duration of the experiment, presumably because it is part of the carbonate rock itself. The content of $\mathrm{Mn}$ is relatively high in the upper and middle level compared with the lower level with a slight decrease over time. With respect to $\mathrm{Co}$, the middle level is high relative to both the upper and lower levels and also shows a slight decrease over time. The Sr content is high in the middle level, low in the upper level and intermediate in the lower level, and the $\mathrm{Sr}$ content seems to be fairly stable in all levels. The content of $\mathrm{Zn}$ is low in the upper level relative to both the middle and lower levels. Collectively, the contents of $\mathrm{Na}, \mathrm{Mg}, \mathrm{Mn}, \mathrm{Co}, \mathrm{Sr}$ and $\mathrm{Zn}$ make the composition of each level distinct for the whole duration of the experiment.

The composition of the water when taking the complete analysis (all 27 elements) into account is reflected by the colour of the dots in Fig. 7. In the upper level $(15.5 \mathrm{~m})$, the dots range from purple and blue colours to blue-green during the first c. $80 \mathrm{~h}$. Then, the composition is fairly stable (blue-green colours) for the next $300 \mathrm{~h}$ after which it changes to compositions dominated by green colours. In the middle level ( $19.5 \mathrm{~m})$, the compositions are marked with pink and purple colours in the first c. $80 \mathrm{~h}$; after this, the compositions are marked blue for the next $300 \mathrm{~h}$ before turning green as is seen in the upper $(15.5 \mathrm{~m})$ level. At the lower level $(23.5 \mathrm{~m})$, the compositions are dominantly marked 


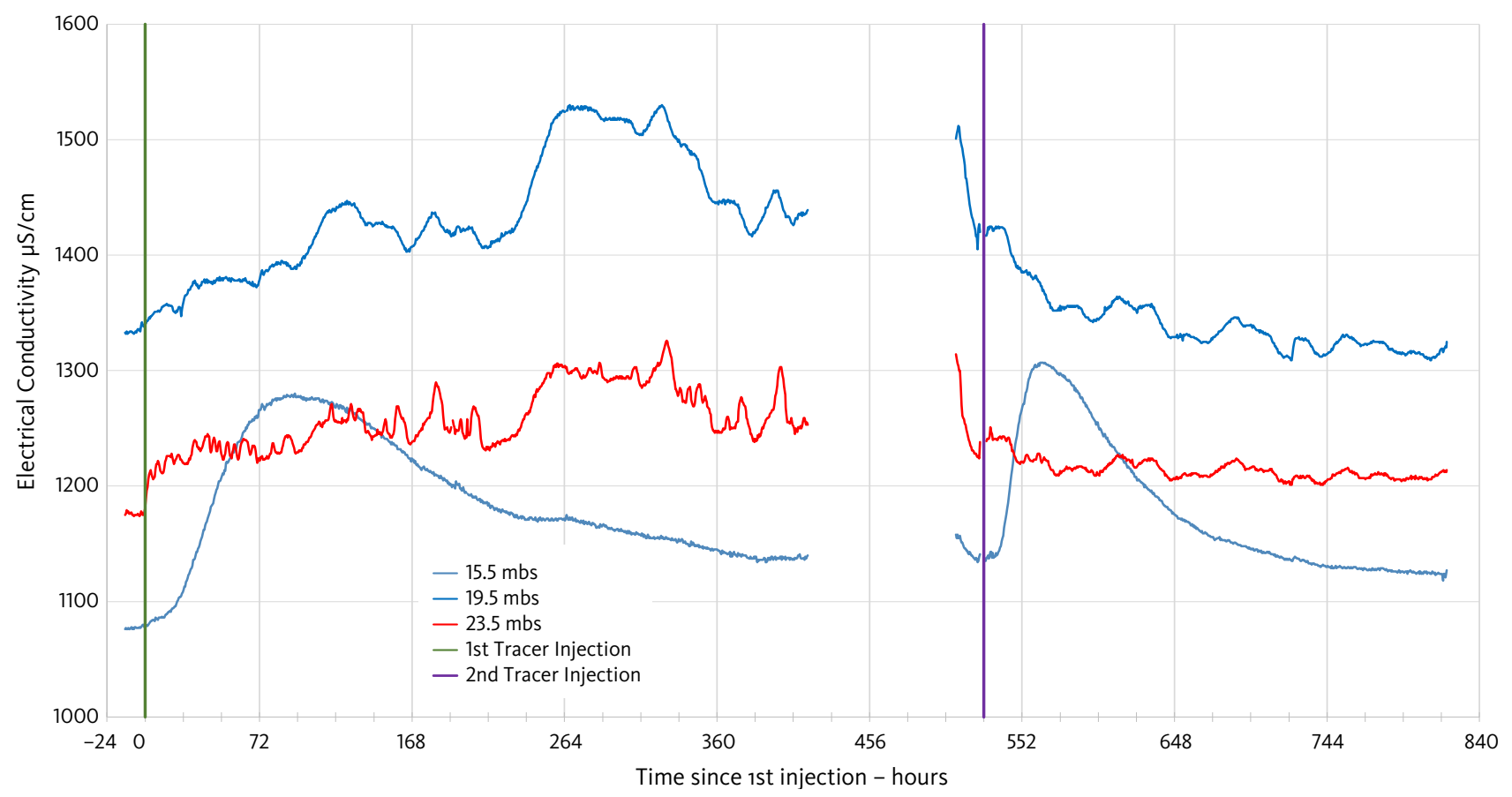

Fig. 6 Electrical conductivity $(\mu \mathrm{S} / \mathrm{cm})$ of the water in the monitoring wells as a function of time. The $\mathrm{NaCl}$ tracer was injected twice during the period on 1 May 2018 at 16.00 and 23 May 2018 at 14.24, indicated by green and purple vertical lines. Abstraction from UB2 was increased from 4.9 to $9.1 \mathrm{~m}^{3} / \mathrm{h}$ during the second tracer test resulting in a faster breakthrough.

with light brown and brown colours for the first c. $80 \mathrm{~h}$. After which green colours also dominate.

\subsection{Comparison with sea water and water from deeper levels}

The composition of the water from the monitoring wells is compared with the composition of water from the Baltic Sea as and water from two deeper wells in the area (Fig. 8). The Mg concentrations of the seawater and the deeper wells are generally high compared with the monitoring wells (Fig. 8). Furthermore, the proportions (ratios) between the elements are different from the monitoring wells. An example is the very high $\mathrm{Mn} / \mathrm{Mg}$, Co/Mg, $\mathrm{Zn} / \mathrm{Mg}$ and $\mathrm{Sr} / \mathrm{Mg}$ ratios in the monitoring wells compared with the seawater (yellow dots in Fig. 8). There is a linear relationship between $\mathrm{Sr}$ and $\mathrm{Mg}$ in the monitoring wells (grey on Fig. 8). The deep well with a sample from $85 \mathrm{~m}$ b.s. (DGU 242.344) has a high chloride content and most trace-element contents are also high (light green dot in Fig. 6). The sample from $40 \mathrm{~m}$ b.s. also has elevated contents of trace elements (yellow dot in grey circle in Fig. 8), and the $\mathrm{Sr} / \mathrm{Mg}$, Co/Mg and $\mathrm{Zn} / \mathrm{Mg}$ ratios are more like those in seawater samples. However, the $\mathrm{Mn} / \mathrm{Mg}$ ratio is different. The hypothetical mixing lines between the infiltrating water and the deep, saline connate water (light green) and Baltic Sea water (yellow) are shown in Fig. 8. The composition of the infiltrating water is inferred to be rainwater containing c. $1 \%$ Baltic Sea water due to the near-coastal position and influx of wind-carried salty aerosols. This corresponds to a chloride concentration of about $40 \mathrm{mg} / \mathrm{l}$, which has been observed in three nearby water-supply wells in chalk about $1 \mathrm{~km}$ north-west of the tracer test site, which seem to have been completely freshened during the Holocene. The composition of the infiltrating water is indicated by the trend lines on Fig. 8.

The water sample from $40 \mathrm{~m}$ (marked with a grey ring) has the same colour as the dots representing the seawater (yellow; Fig. 8). This implies that their hydro-chemical fingerprints are alike, that is, they are very close to each other in the 27-dimensional space of the geochemical dataset.

\section{Discussion}

Trace-element analysis of freshwater has previously been tested as a method for understanding the waterrock interactions in a system. Schürch et al. (2004) suggested that the groundwater geochemistry in a chalk aquifer is dominated by incongruent reactions with the fine-grained carbonate sediments, which release trace-element impurities into the water. Khadra et al. (2017) found that the chemical differences between limestone and dolomitic limestone were important factors in explaining the observed variation in the concentration of trace elements in fresh groundwater. 

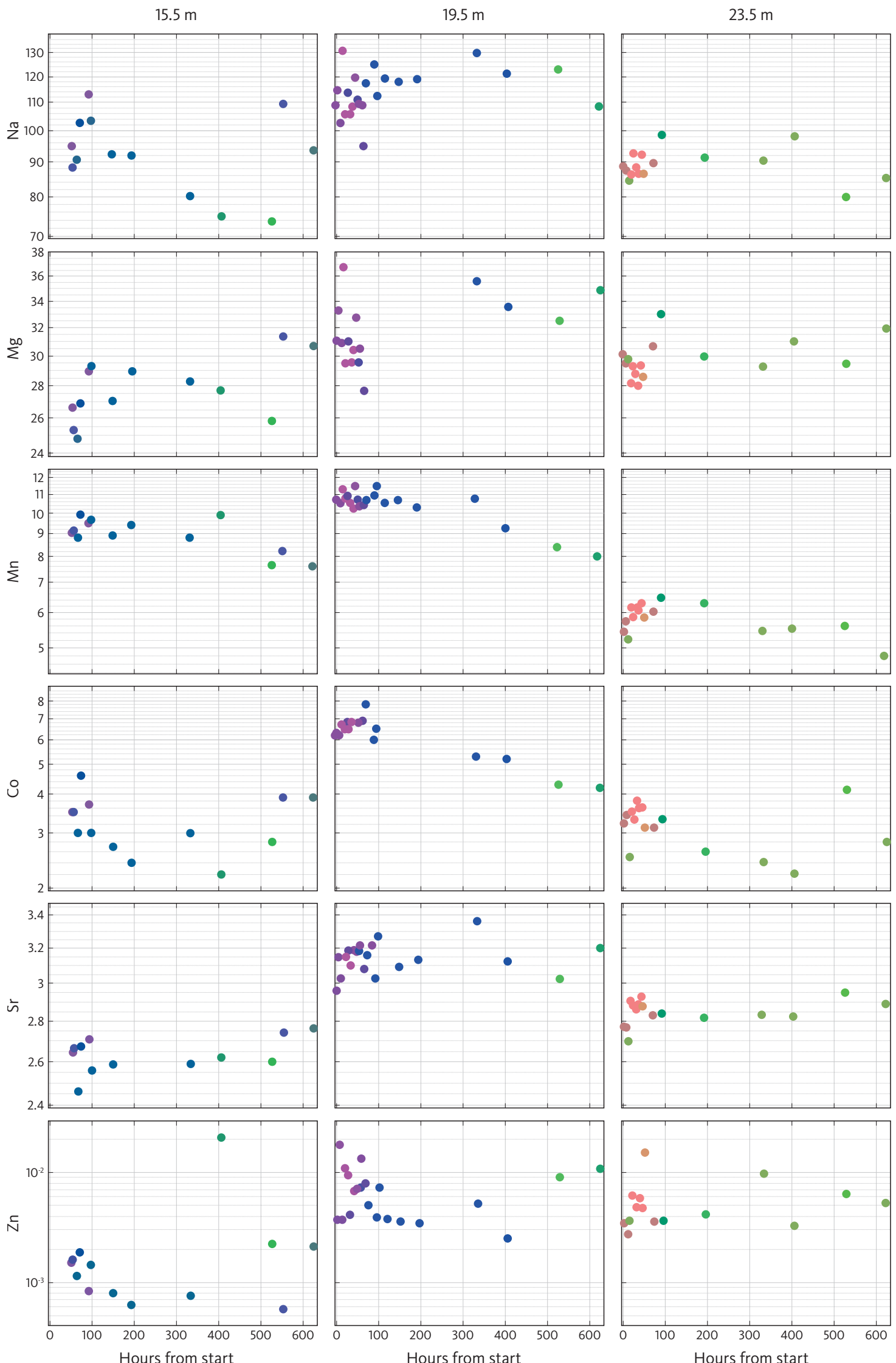

Fig. 7 Concentrations (ppm) of $\mathrm{Na}, \mathrm{Mg}, \mathrm{Mn}, \mathrm{Co}, \mathrm{Sr}$ and $\mathrm{Zn}$ in the extracted water from the three filters at $15.5 \mathrm{~m}, 19.5 \mathrm{~m}$ and $23.5 \mathrm{~m}$ as a function of time (hours) from 1 May to 4 June 2018. Depth of sampling points is shown at the top. Note that the $Y$-axis is on a log scale apart from Mg. The position of the points represents the actual measurements, whereas the colour of the points represents the SOM derived geochemical fingerprint. 

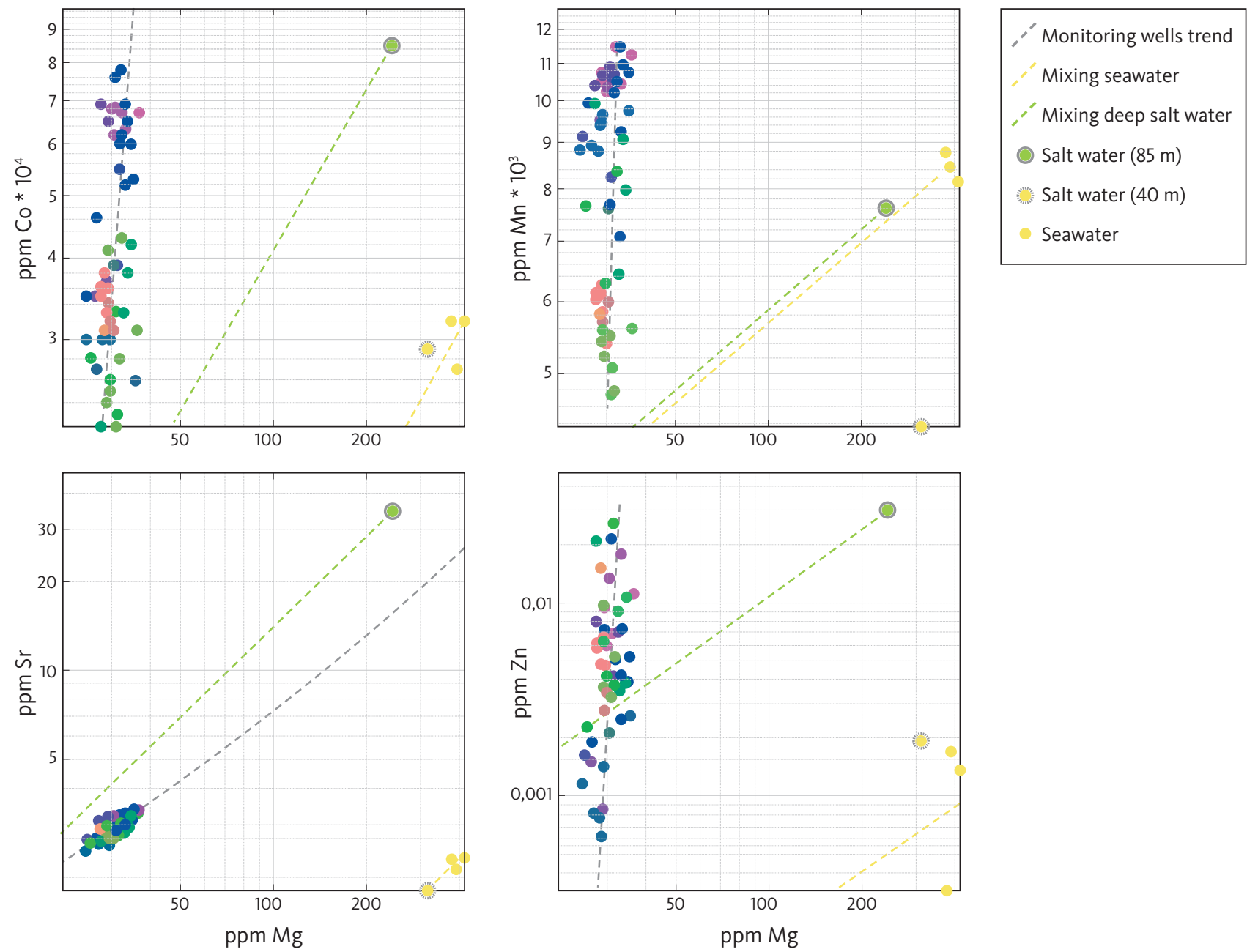

Fig. 8 Concentrations (ppm) of $\mathrm{Co}, \mathrm{Mn}, \mathrm{Sr}$ and $\mathrm{Zn}$ and versus ppm $\mathrm{Mg}$ in samples from the pumping experiment compared with Baltic seawater and two deeper wells on Falster at $85 \mathrm{~m}$ b.s. and $40 \mathrm{~m}$ b.s. Note that it is a log-log plot.

Yuan et al. (2019) found that multi-element fingerprinting can be useful for assessing hydrological connectivity across the landscape and indicate that element concentrations are affected not only by land use but also by hydrogeological characteristics.

The trace-element composition of the groundwater at $15.5,19.5$ and $23.5 \mathrm{~m}$ b.s. (Fig. 7) is distinct from each other at early times in the experiment, before the composition of the water is homogenised by the recirculation. Apart from $\mathrm{Na}$, these elements occur in different minerals in the chalk with $\mathrm{Mg}$ and Sr mainly in carbonates, Zn and Co mainly in sulphides and Mn mainly in oxides. The content, composition and/or reactivity of these minerals presumably vary among the different stratigraphic levels. The most likely explanation for the variation and distinct chemistry of the water at the different stratigraphic levels at the start of the experiment is that the different trace-element distributions in the water reflect the variable composition of the chalk with depth, that is, the content of clay minerals, carbonates and sulphides and variable trace-element composition of these minerals. This implies that the water composition has evolved due to geochemical reactions with the chalk at various stratigraphic levels, as suggested by Schürch et al. (2004). This could be due to variations in trace-element composition at the time of formation of the chalk, a result of post-depositional solution or precipitation or some other type of reaction, such as sorption of the trace elements on the mineral surfaces or variations in the contents of minerals due to glaciotectonic redistribution of sediments. However, the mechanism controlling the variation in trace-element concentrations is not clear.

Up-coning and seawater intrusion were suggested to be responsible for increasing salinity in wells close to each other in a similar coastal carbonate aquifer about $100 \mathrm{~km}$ north of the Falster test site (Thorn 2011). If the trace element concentrations in the aquifer were a result of simple mixing between meteoric water and Baltic Sea water, the samples should fall on a mixing line between the two sources. Furthermore, the colour of the dots representing the compositional variation should reflect 
this (Fig. 8). However, this is not the case, and thus, the elevated salinity in the monitoring wells is unlikely to be the result of simple dilution of Baltic Sea water. Similarly, if the trace element concentrations in the aquifer were a result of simple mixing between meteoric water and connate water from deeper levels, the samples should likewise fall on a mixing line between these two sources. This is not the case, as the trace-element composition is also distinct from the connate saline water from the deeper levels of the chalk aquifer (Fig. 8), suggesting that elevated salinity in the wells is not simply caused by up-coning of saline water from below.

After c. $80 \mathrm{~h}$, the composition of the water in the monitoring wells changes slightly at all three levels as seen in the change of the colours of the dots marking the geochemical fingerprint of the water derived from the SOM analysis (Fig. 7). The geochemical fingerprint of the water is very distinct at the $19.5 \mathrm{~m}$ level with bright pink dots and light brown dots at the $23.5 \mathrm{~m}$ level. At the $19.5 \mathrm{~m}$ level, the composition changes after c. 80 $\mathrm{h}$ and is marked by blue dots for the following $300 \mathrm{~h}$. The composition of the water at this level is still rather different from the other two levels, and the reason for the conservative nature of the composition here may be caused by the fairly high levels of trace elements in the water. After c. 500 h, the composition at the 19.5 $\mathrm{m}$ level changes, reflected by green dots (Fig. 7). At the $23.5 \mathrm{~m}$ level, the change to green dots occurs after $c$. $80 \mathrm{~h}$, and at the $15.5 \mathrm{~m}$ level, the green dots occur after c. $500 \mathrm{~h}$. However, the colour of the dots at the $15.5 \mathrm{~m}$ level becomes blue-green after c. $80 \mathrm{~h}$ indicating that the composition is developing towards the green dots after $500 \mathrm{~h}$ at $19.5 \mathrm{~m}$ and after $80 \mathrm{~h}$ at $23.5 \mathrm{~m}$. At 15.5 $\mathrm{m}$, the tracer concentration peaks earlier than at deeper levels (Fig. 6) and seems to be flushed out earlier than the other levels. This is probably because the chalk is heavily fractured here (Fig. 2B).

The shift towards greenish colours over time at all levels indicates that the samples become statistically more homogeneous, which is most likely an effect of the recirculation mixing the water from all levels and smoothing out their characteristic fingerprints. This indicates that the fingerprint characteristics must be a feature that develops over time through water-rock interactions.

The water analysed from $40 \mathrm{~m}$ b.s. in the DGU 242.375 well located $100 \mathrm{~m}$ from the Baltic Sea is very similar to the water from the Baltic Sea (Fig. 8) with respect to the content of $\mathrm{Mg}, \mathrm{Sr}$ and Co. Furthermore, the dot that reflects the overall geochemical fingerprint, taking all the 27 elements into account, has the same colour as that for seawater (yellow). This implies that the geochemical fingerprint in this well is similar to the seawater and that the water here is derived from the
Baltic Sea. The different Mn content may be caused by trapping of $\mathrm{Mn}$ on oxides towards the well and/or the well screen.

The present position of the saltwater-freshwater interface at c. $30-40 \mathrm{~m}$ b.s. (c. -30 to $-40 \mathrm{~m}$ a.s.I.) is controlled by the depth and distribution of hydraulic active fractures in the chalk, as was found for sites on the island of Sjælland, c. $100 \mathrm{~km}$ to the north of Falster where the interface is found between -45 and $-70 \mathrm{~m}$ a.s.l. (Larsen et al. 2006). The thinner freshwater zone on the island of Falster might be explained by a number of processes, including the ablation history of retreating glaciers during past glaciations, the marine setting of the aquifer during most of the Holocene and finally more recent land reclamation on Falster, which resulted in very low groundwater recharge since the early 1860 s.

Multi-element fingerprinting of water is not commonly used in Northern Europe, and the results of the present investigation suggest that this can be a useful method to investigate water-rock interactions, water provenance and the sources of dissolved chloride. This information is important when planning measures to control saltwater intrusion and protect drinking water resources such as managed aquifer recharge of desalinised brackish groundwater from deeper parts of the aquifer. The results of this study and of previous studies by Rasmussen et al. (2013), Pedersen et al. (2018) and Hinsby et al. (2018) clearly demonstrate that a sound understanding of local geological and geochemical features of aquifers is a prerequisite for the protection of water-supply wells from saltwater intrusion of various sources in coastal areas.

\section{Conclusions}

Water extracted from a slightly saline aquifer on Falster has distinctly different hydro-chemical fingerprints depending on the stratigraphic levels from where it is extracted. This suggests that the composition has evolved by interaction with the rock. The slightly saline character of the water is probably due to incomplete refreshing of the aquifer during the Holocene. This could again be caused by the very low relief and flow in the area.

Water composition changes with time during the tracer experiment, probably caused by the flushing of the reservoir with re-injected water. Introduction of the $(\mathrm{NaCl})$ tracer may also have caused ion exchange, thus mobilising other cations in the reservoir.

Comparisons of aquifer water with Baltic Sea water and deep connate water show that the observed compositions cannot be generated by mixing these sources with the meteoric recharge. However, the hydro-chemical composition/fingerprint of the water in another well extracted at $40 \mathrm{~m}$ b.s. is very close to seawater, 
suggesting that the water here contains a high fraction of seawater. This is likely because the well is located close to (c. $100 \mathrm{~m}$ from) the Baltic Sea.

The statistical analysis, based on an unsupervised machine-learning algorithm, SOM, has proved to be a very effective way to facilitate interpretation of a large number of variables and thus understand the compositional variation in an aquifer. Using multi-element analysis combined with SOM analysis/fingerprinting may also be useful in future studies of variations in groundwater quality and, for example, in characterising the source of chloride in coastal aquifers.

\section{Acknowledgements}

The authors would like to thank Olga Nielsen (GEUS) for the analytical work, Per Jensen (GEUS) for help during the fieldwork and Peer Jørgensen (Copenhagen University) for the development of the partly automated sampling and monitoring system in CMT wells.

\section{Additional information}

\section{Funding}

The study was conducted as part of the SUBSOL project (www.subsol. org) that received funding from the European Union's Horizon 2020 research and innovation programme under grant agreement no. 642228.

\section{Author contributions}

All: Investigation and writing (original draft, review and editing). CK and LJK: Data curation and methodology. KH: Project administration, conceptualisation and funding acquisition. RJ: Conceptualisation and methodology. PR: Conceptualisation.

\section{Additional files}

Two additional files are available at: https://doi.org/10.22008/FK2/ Q8YF8V

\section{References}

Bonnesen, E.P., Larsen, F., Sonnenborg, T.O., Klitten, K. \& Stemmerik, L. 2009: Deep saltwater in Chalk of North-West Europe: origin, interface characteristics and development over geological time, Hydrogeology Journal 17, 1643-1663. https://doi.org/10.1007/s10040-009-0456-9

Dalla Libera, N., Pedretti, D., Tateo, F., Mason, L., Piccinini, L. \& Fabbri, P. 2020: Conceptual model of arsenic mobility in the shallow alluvial aquifers near Venice (Italy) elucidated through machine learning and geochemical modeling. Water Resources Research 56, e2019WR026234. https://doi.org/10.1029/2019wr026234

Edmunds, W.M., Cook, J.M., Darling, W.G., Kinniburgh, D.G., Miles, D.L., Bath, A.H., Morgan-Jones, M. \& Andrews, J.N. 1987: Baseline geochemical conditions in the Chalk aquifer, Berkshire, U.K.: a basis for groundwater quality management. Applied Geochemistry 2, 251-274. https://doi.org/10.1016/0883-2927(87)90042-4

Henriksen, H.J., Voutchkova, D., Troldborg, L., Ondracek, M., Schullehner, J. \& Hansen, B. 2019: National Vandressource Model Beregning af udnyttelsesgrader, afsænkning og vandløbspåvirkning med DK model 2019. GEUS report 2019/32, 84 pp.

Hinsby, K., Condesso de Melo, M.T. \& Dahl, M. 2008: European case studies supporting the derivation of natural background levels and groundwater threshold values for the protection of dependent ecosystems and human health. Science of the Total Environment 401, 1-20. https://doi.org/10.1016/j.scitotenv.2008.03.018
Hinsby, K., Jessen, S., Larsen, F. \& Postma, D. 2012: A groundwater chemistry and multi-tracer study of sources of salt water intrusion the Island of Falster, Denmark. 22nd Salt Water Intrusion Meeting, SWIM2012, 18-22 June, Buzios, Brazil.

Hinsby, K., Johnsen, A.R., Rasmussen, P., Sonnenborg, T.O., Sørensen, S.R., Postma, D., Thorn, P., Scharling, P.B. \& Gudbjerg, J. 2016: Water4Coasts - new methods for integrated management and protection of coastal aquifers, 160 pp. Copenhagen: Danish Ministry of Environment and Food.

Hinsby, K. et al. 2018: D2.2 Road map for full scale implementation of SWS for fractured chalk aquifer. 68 pp. Deliverable for the EU project SUBSOL. www.subsol.org

Kalteh, A.M., Hjorth, P. \& Berndtsson, R. 2008: Review of the self-organizing map (SOM) approach in water resources: analysis, modelling and application. Environmental Modelling \& Software 23, 835-845. https:// doi.org/10.1016/j.envsoft.2007.10.001

Khadra, W.M., Stuyfzand, P.J. \& van Breukelen, B.M. 2017: Hydrochemical effects of saltwater intrusion in a limestone and dolomitic limestone aquifer in Lebanon. Applied Geochemistry 79, 36-51. https:// doi.org/10.1016/j.apgeochem.2017.02.005

Kim, K.H., Yun, S.T., Yu, S., Choi, B.Y., Kim, M.J. \& Lee, K.J. 2020: Geochemical pattern recognitions of deep thermal groundwater in South Korea using self-organizing map: identified pathways of geochemical reaction and mixing. Journal of Hydrology 589, 125202. https://doi. org/10.1016/j.jhydrol.2020.125202

Kohonen, T. 1982: Self-organized formation of topologically correct feature maps. Biological Cybernetics 43, 59-63. https://doi.org/10.1007/ BF00337288

Kohonen, T. 1990: The self-organizing map. Proceedings of the IEEE 78, 1464-1480. https://doi.org/10.1109/5.58325

Kohonen, T. 2001: Self-organizing maps. Heidelberg: Springer-Verlag Berlin. https://doi.org/10.1007/978-3-642-56927-2

Kohonen, T. 2013: Essentials of the self-organizing map. Neural Networks 37, 52-65. https://doi.org/10.1016/j.neunet.2012.09.018

Larsen, F., Sonnenborg, T., Madsen, P. 2006: Saltvandsudvaskning i Danienkalk og Skrivekridt: detailundersøgelser i Karlslunde værkstedsområde [Saltwater transport in the Danian Limestone and Chalk: detailed studies from Karlslunde study area]. Partial report no. 6 , 2006/21, 1-103. Copenhagen: Geological Survey of Denmark and Greenland.

Ødum, H. \& Christensen, W. 1936: Danske Grundvandstyper og deres geologiske optræden. Danmarks Geologiske Undersøgelse III. Række 26, 183 pp.

Pedersen, S.A.S., Gravesen, P. \& Hinsby, K. 2018: Chalk-glacitectonite, an important lithology in former glaciated terrains covering chalk and limestone bedrock. Geological Survey of Denmark and Greenland Bulletin 41, 21-24. https://doi.org/10.34194/geusb.v41.4333

Rasmussen, P., Sonnenborg, T.O., Goncear, G. \& Hinsby, K. 2013: Assessing impacts of climate change, sea level rise, and drainage canals on saltwater intrusion to coastal aquifer. Hydrology and Earth System Sciences 17, 421-443. https://doi.org/10.5194/hess-17-421-2013

Schürch, M., Edmunds, W.M. \& Buckley, D. 2004: Three-dimensional flow and trace metal mobility in shallow Chalk groundwater, Dorset, United Kingdom. Journal of Hydrology 292, 229-248. https://doi. org/10.1016/j.jhydrol.2004.01.004

Thorn, P. 2011: Groundwater Salinity in Greve, Denmark: determining the source from historical data. Hydrogeology Journal 19(2), 445-461. https://doi.org/10.1007/s10040-010-0680-3

Yuan, Y., Zhu, X., Mushet, D.M. \& Otte, M.L. 2019: Multi-element fingerprinting of waters to evaluate connectivity among depressional wetlands. Ecological Indicators 97, 398-409. https://doi.org/10.1016/j. ecolind.2018.10.033

Zuurbier, K., Raat, K.J., Paalman, M., Oosterhof, A.T. \& Stuyfzand, P.J. 2017: How subsurface water technologies (SWT) can provide robust, effective, and cost-efficient solutions for freshwater management in coastal zones. Water Resources Management 31, 671-687. https://doi. org/10.1007/s11269-016-1294-X 